\title{
SUDECK'S ATROPHY IN THE HAND
}

\author{
L. W. Plewes, Kensworth, Bedfordshire, England \\ From the Luton and Dunstable Hospital, Luton
}

Sudeck's atrophy, or post-traumatic osteodystrophy, is considered by most surgeons in Great Britain to be a relatively rare condition, although in Europe and North America it is claimed by some to be the most common cause of prolonged disability after injury (Jordan 1940, Gurd 1938, Scheibe and Karitzky 1954, Herrmann, Reineke and Caldwell 1942). Only one British contribution appears in the extensive world literature on the subject (Middleton 1937), and Watson-Jones considers it to be a severe form of disuse atrophy (Watson-Jones 1952).

Much has been written about the treatment of this condition, particularly in relation to surgical attacks on the sympathetic system (Brïcke 1946, Evans 1946, Heyman 1924, Herrmann 1935, Toumey 1948, Kiær 1948), parasympathetic stimulation (Middleton 1937), the application of plaster splints, x-ray therapy (Mumford 1938), physical therapy (Sudeck 1938, Noble and Hauser 1926, Jordan 1940), and more recently on the use of vasomotor relaxants and cortisone (Dwyer 1952, Rose 1953, Roland 1952, Birkenfeld 1954, Marti 1954).

It is the purpose of this paper to show firstly that Sudeck's syndrome of the acute type is not uncommon in the hand and, secondly, that it responds to conservative treatment if the diagnosis is made within six weeks of the onset of symptoms. No attempt will be made to add yet another theory to explain the etiology, but some observations on the occurrence of thickening of the palmar fascia in association with Sudeck's syndrome will be recorded.

TABLE I

Causative factors in Thirty-seven Cases of Sudeck's Atrophy

\begin{tabular}{|c|c|c|c|c|c|c|}
\hline Colles's fracture & $\cdot \quad \cdot$ & - & $\cdot$ & - & . & $\cdot \begin{array}{c}16 \\
\text { (14 women) }\end{array}$ \\
\hline Smith's fracture & • & - & - & - & - & $\begin{array}{c}5 \\
\text { (4 women) }\end{array}$ \\
\hline $\begin{array}{c}\text { Fractures about } t \\
\text { Scaphoid } \\
\text { Triquetral } \\
\text { Metacarpal }\end{array}$ & $\begin{array}{c}\text { the wrist: } \\
. \\
. \\
. \\
.\end{array}$ & . & $\dot{\text { : }}$ & : & $\dot{\cdot}$ & $\begin{array}{l}1 \\
1 \\
2\end{array}$ \\
\hline \multicolumn{4}{|c|}{ Finger injuries: } & $\cdot$ & . & $\begin{array}{l}2 \\
1\end{array}$ \\
\hline \multicolumn{6}{|c|}{ Crush injuries of hand and wrist (without fracture) } & 3 \\
\hline \multicolumn{6}{|c|}{ Brachial plexus injuries (one with dislocated shoulder) } & 2 \\
\hline $\begin{array}{l}\text { Arm injuries: } \\
\text { Dislocation } \\
\text { Fracture of } h\end{array}$ & $\begin{array}{l}\text { of elbow } \\
\text { humerus }\end{array}$ & . & . & • & . & $\begin{array}{l}1 \\
1\end{array}$ \\
\hline Hemiplegia & . & - & • & • & . & 1 \\
\hline \multicolumn{2}{|c|}{ Burn of forearm and hand } & . & - & - & . & 1 \\
\hline
\end{tabular}

\section{INCIDENCE AND CLINICAL FEATURES}

During the three years 1952-54, 80,000 new patients were seen in the Accident Services of the Luton and Hitchin Group of hospitals, and in this period Sudeck's syndrome was recognised on thirty-seven occasions. Two-thirds of these cases were in women, and the 


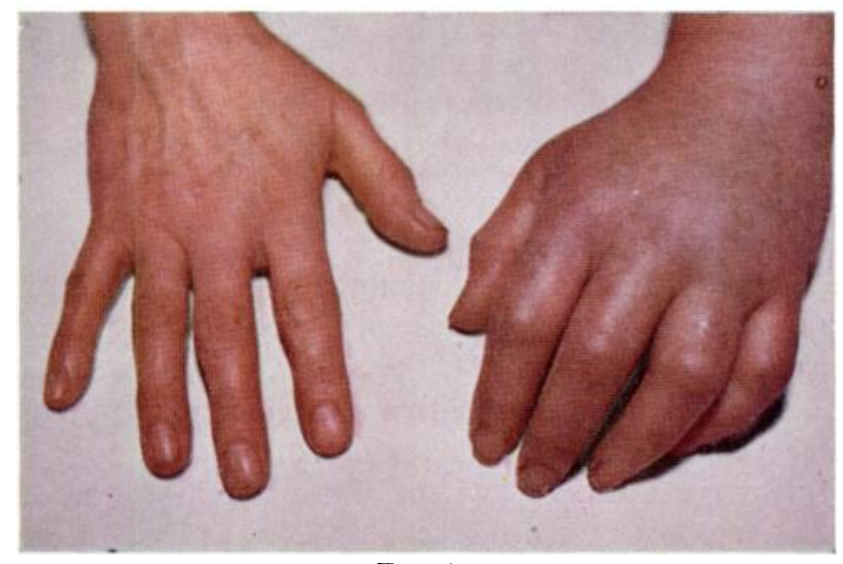

Fig. 1

An example of Sudeck's syndrome three weeks after the onset of symptoms. Swelling and colour changes are accompanied by partial obliteration of skin creases and loss of Lange's lines. The fingers are fixed in flexion and already show tapering. The swelling in this case is more than usual (120 cubic centimetres).

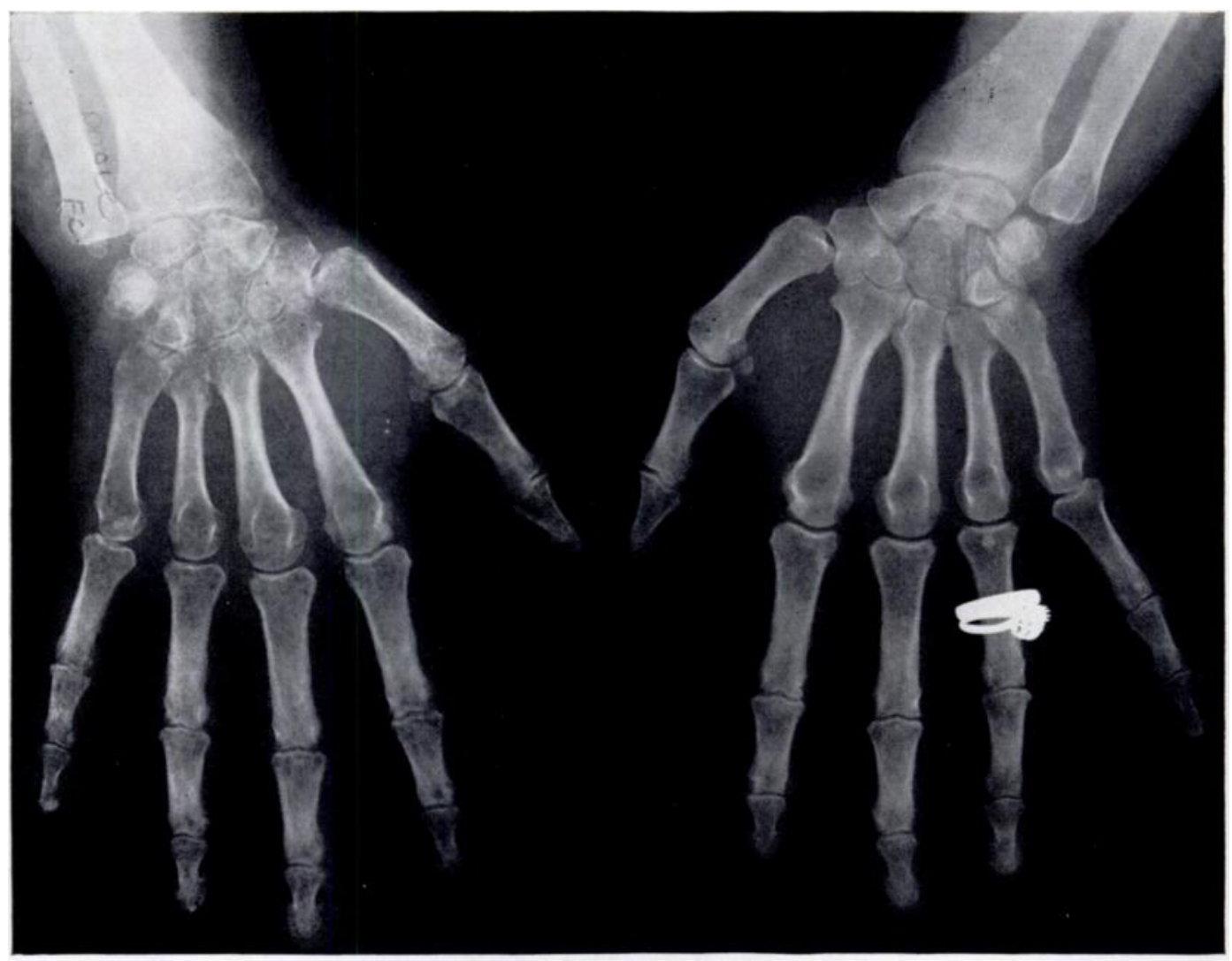

FIG. 2

Typical spotty appearance of Sudeck's atrophy involving carpus, metacarpals and phalanges. The shafts of the metacarpals and phalanges are only slightly affected. 
average age of the whole group was fifty-eight years (youngest thirty-three, oldest seventy-six). The causative factor was most frequently an injury in the region of the wrist (Table I) (Bethge and Meyer 1953).

The symptoms of pain, swelling and dysfunction developed at an average of eight weeks after injury and were accompanied by the following signs: hyperaemia, loss of Lange's lines, obliteration of skin creases, loss of tissue turgor in the pulp, changes in skin temperature and colour, nail ridges, limitation of movement and tenderness. Power of grip was grossly impaired (average 10 per cent of normal) and the volume of the hand increased by 10-20 per cent.

The pain is burning or aching in character and several patients described it as being deep. It is not relieved by splinting or by short-wave diathermy. The swelling is not due entirely to oedema. When the hand volume is increased by as much as 100 cubic centimetres pitting on pressure can be demonstrated, but when this oedema has responded to treatment there is left a visible and palpable thickening of the soft tissues. The degree of obliteration of the

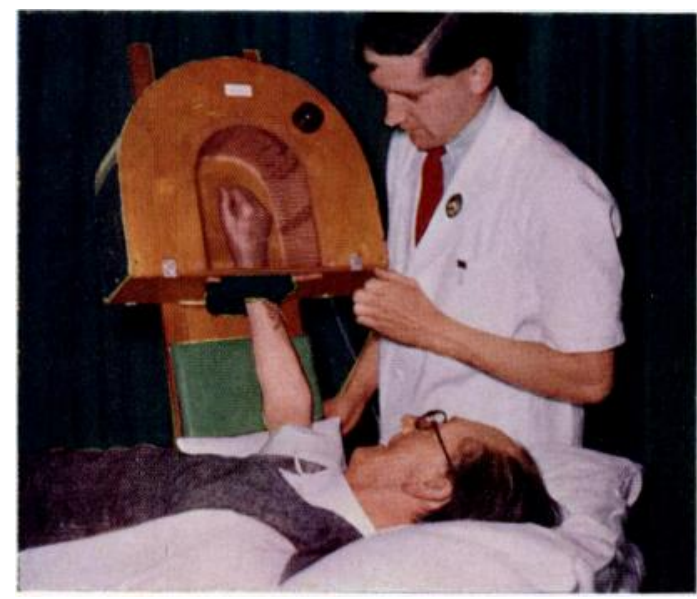

Fig. 3

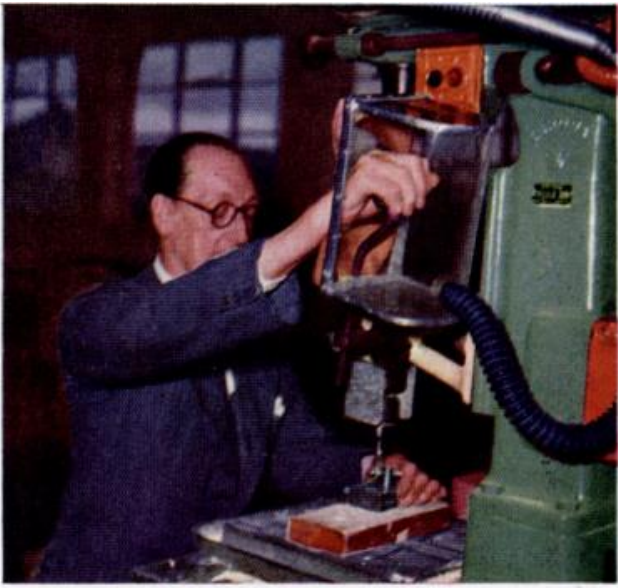

Fig. 4

Figure 3-The physiotherapist is showing the patient how to exercise the intrinsic muscles while the hand is elevated and covered with wax and polythene in a warm cabinet. Figure 4-The operating lever of this drilling machine is surrounded by a Perspex cabinet warmed by hot air. The hand works above shoulder level.

skin creases opposite the joints corresponds with the amount of swelling, but the loss of Lange's lines is not related to the swelling of the soft tissues. Even when the volume of the hand returns to normal, Lange's lines remain less marked for many months.

The hand is held immobile with the fingers in a position of semiflexion (Fig. 1), and attempts at movement result in only a small range at the metacarpo-phalangeal joints. The terminal pulps of the fingers are tapered and feel less resilient than normal, and the return of the skin colour after pressure is brisk. Transverse ridges appear on the nails. In the early stages the hand is deep pink and the skin feels warm. Later, the skin takes on a mottled cyanotic appearance and feels cold and dry.

Radiographic appearance-The characteristic radiographic appearance is not present in the early stages, but takes six to eight weeks to show, and it is for this reason that the diagnosis is often overlooked. The spotty rarefaction that involves the ends of the phalanges and metacarpals is unmistakable (Fig. 2). Sometimes the carpus and the distal ends of the radius and ulna are involved, whereas the shafts of the bones are only slightly affected. The spotty appearance is quite unlike the generalised ground-glass appearance seen in disuse atrophy, which takes a much longer time to develop. Sometimes the clinical signs and symptoms have disappeared by the time radiographic changes can be seen. On occasions pain and dysfunction in more proximal joints follow (elbow and shoulder); here again, the same radiographic appearance can be seen but not until six weeks after the onset of symptoms in these joints. 
In 1900 Sudeck described these typical radiographic appearances and considered them to be abnormal. More recently he ascribed them to an exaggerated but normal process of inflammation and repair (Sudeck 1938). It is true that slight radiographic changes can be seen in a small proportion of hands after injury without the signs and symptoms of Sudeck's syndrome. In a recent analysis of one hundred patients over the age of fifty with wrist fractures, radiographs taken eight weeks after the removal of plaster showed slight subchondral spotty osteoporosis in six cases. Well marked radiographic changes were always accompanied by signs and symptoms of Sudeck's syndrome.

\section{TREATMENT}

Treatment in our clinic is entirely conservative and consists in the application of heat, elevation of the limb, and graded function. We find that hot wax is just as effective in the relief of pain as blocking the cervical sympathetic chain with procaine. Elevation reduces the oedema by a measurable amount. Gradually increased function in conjunction with heat and elevation results in the relief of symptoms in every early case in an average time of six

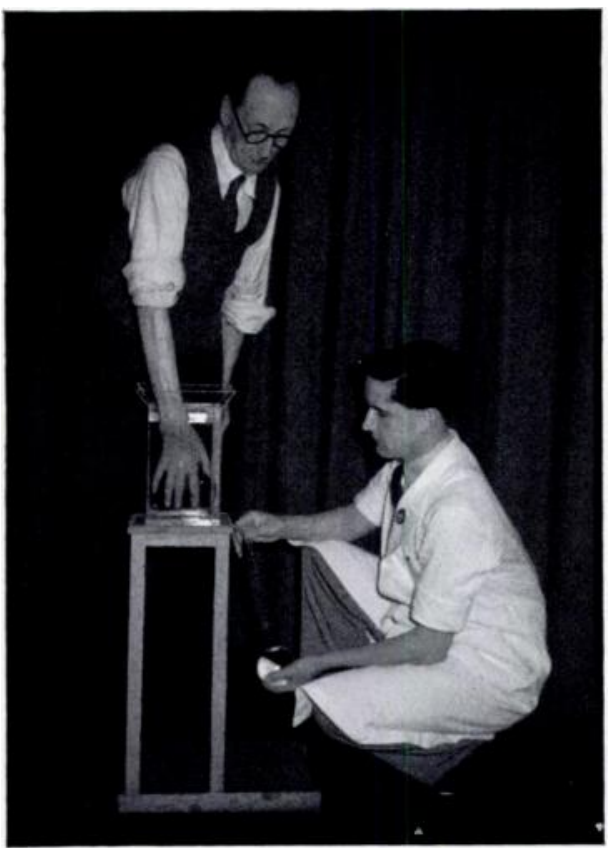

Fig. 5

This simple hand volume-measuring equipment is accurate to within 1 per cent because the hand and fingers are always trapped in a constant position. weeks. During the last four years the technique of applying hot wax, elevation and exercise therapy has been improved and is now standardised.

The hand is immersed in hot molten wax for a minute or so until the hand feels warm and is then covered with a polythene glove. The limb is then elevated on an inclined plane with a completely enclosed radiant heat cradle to keep the hand temperature between 105 and 110 degrees Fahrenheit (Fig. 3). Exercises for the intrinsic muscles are then taught and supervised by the physiotherapist. This procedure is carried out twice a day for half an hour each time. The rest of the day is spent in the remedial workshop. The patient sits on a low chair and operates a machine with the operating lever raised so that the affected hand is kept above the level of the shoulder. Warmed air is blown into a transparent cabinet which surrounds the hand and maintains a temperature of 105 degrees Fahrenheit (Fig. 4). For the first week or two simple analgesics are necessary but they can be nearly always discontinued by the third week.

Each day the power of grip is recorded and the volume of the hand is measured with equipment designed by M. Eccles, a therapist on our staff (Fig. 5). This volume-measuring equipment is accurate to within 1 per cent and is based on the principle of water displacement.

Two case histories will serve to illustrate the salient features of Sudeck's syndrome.

\section{CASE REPORTS}

Case 1-A woman of seventy crushed the tip of her right ring finger in a folding chair. One stitch was required to close the laceration of the pulp and the wound healed in ten days, with some puckering of the scar. A month later she developed pain in the ring finger and in the two adjacent fingers. The pain gradually became worse and the three fingers stiffened. When she began to lose sleep she came 
to hospital ten weeks after the injury. The three ulnar fingers were deep pink in colour, swollen and almost completely rigid. The skin creases opposite the joints were partly obliterated and Lange's lines were barely visible. There was a flame-coloured staining under the distal part of the nail of the ring finger and the healed laceration of the pulp was slightly tender. The three ulnar fingers were dry and cold. Radiographs showed slight spotty changes in the subchondral area of all the small joints of the ulnar three fingers. A month later there was a well marked Sudeck's atrophy of the ulnar side of the hand (Fig. 6). Volume of hand (Fig. 7) and power of grip (Fig. 8) returned to normal

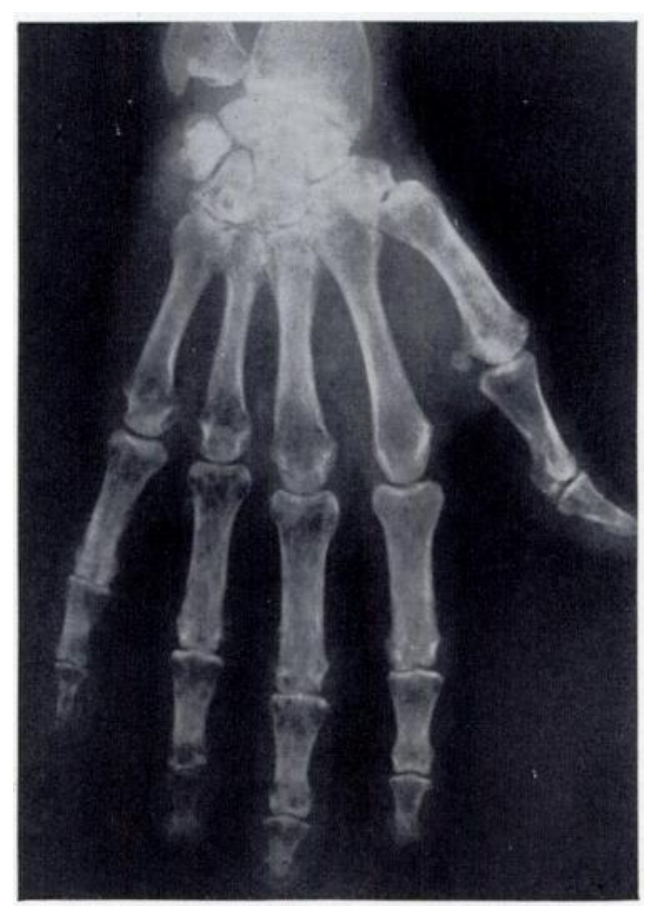

FIG. 6

Case 1-There is a well marked osteoporosis of the terminal phalanx of the ring finger. Sudeck's changes are apparent in the three ulnar fingers and their metacarpals. The thumb and index finger are unaffected.

after three months' intensive treatment, and at this stage the physiotherapist noticed some thickening of the palmar fascia on the ulnar side of the palm. Six months later the hand was normal in all respects, except for a well marked Dupuytren's contracture on the ulnar side of the hand with dimpling of the skin of the palm, but with only slight limitation of extension of the ring and little fingers.

Case 2-A boxmaker aged fifty-four sustained a Smith's fracture which was reduced and splinted two hours after injury. The patient went back to modified work while in plaster, which was kept on for six weeks. Three days after the plaster was removed there was a sudden onset of pain, swelling and stiffness in the hand. It became deep pink in colour and function was lost. Lumps were found on the ulnar side of the palmar fascia. At the time of the first treatment the volume of the hand was 578 cubic centimetres (other hand 470 cubic centimetres) and the power of grip was $6 \mathrm{lb}$. (other hand $70 \mathrm{lb}$.) (Figs. 9 and 10). Intensive daily treatment for eight weeks resulted in a diminution of the volume of the hand to 454 cubic centimetres and an increase of power of grip to $58 \mathrm{lb}$., and the patient returned to normal work. Radiographs showed obvious changes (Fig. 11). The thickening of the palmar fascia was well marked a year after the onset of symptoms and there was no involvement of the other palm.

\section{THE ASSOCIATION OF SUDECK'S ATROPHY WITH THICKENING OF THE PALMAR FASCIA}

The thickening of the palmar fascia described in the above examples was first noticed by Eccles (1956) and it soon became apparent that it was a regular feature of this syndrome. In six cases there was palpable nodular thickening of the palmar fascia in both hands, in four

VOL. $38 \mathrm{~B}$, NO. 1, FEBRUARY 1956

$\mathrm{N} 2{ }_{(+)}$ 
the condition was more evident on the side affected by Sudeck's syndrome, in fifteen others nodules were felt on the affected side only, and in three the thickening developed while the patient was under observation during treatment.

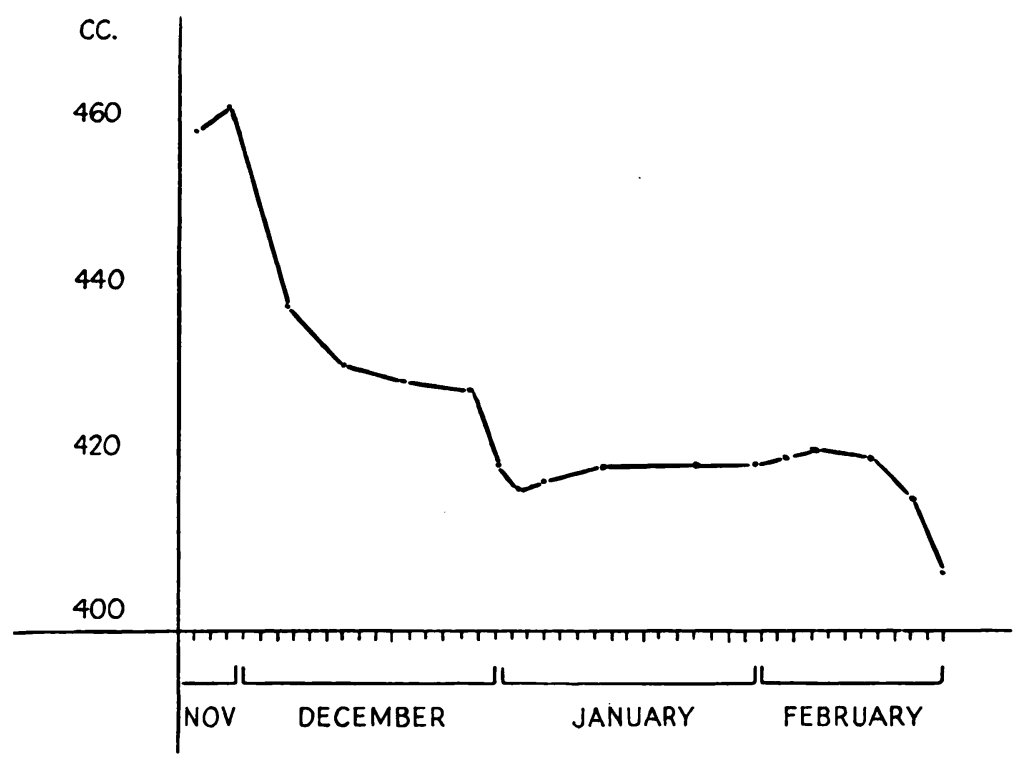

Fig. 7

Case 1-Volume chart of right hand. (Left hand 405 cubic centimetres.)

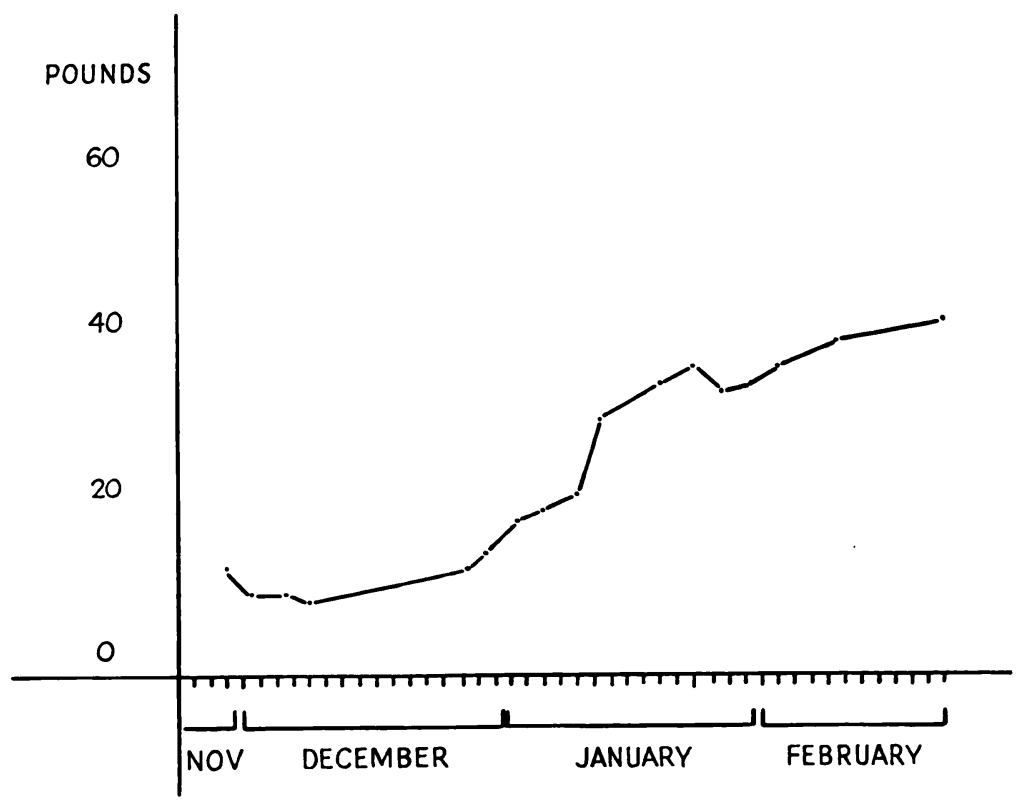

Fig. 8

Case 1-Power of grip chart, right hand. (Left hand $46 \mathrm{lb}$.)

Established Dupuytren's contracture (thickening of part of the palmar fascia with dimpling of the skin and deformity of at least one digit) was present before the onset of Sudeck's atrophy in three cases (bilateral in two), and in each of these the condition got worse for a time. One patient developed a contracture while under treatment, and four patients were noticed to 
have contractures on the affected side at some stage in treatment, but no notes were made about the deformity when first seen. In only one patient of the total of thirty-seven was the palmar fascia not thickened or contracted.

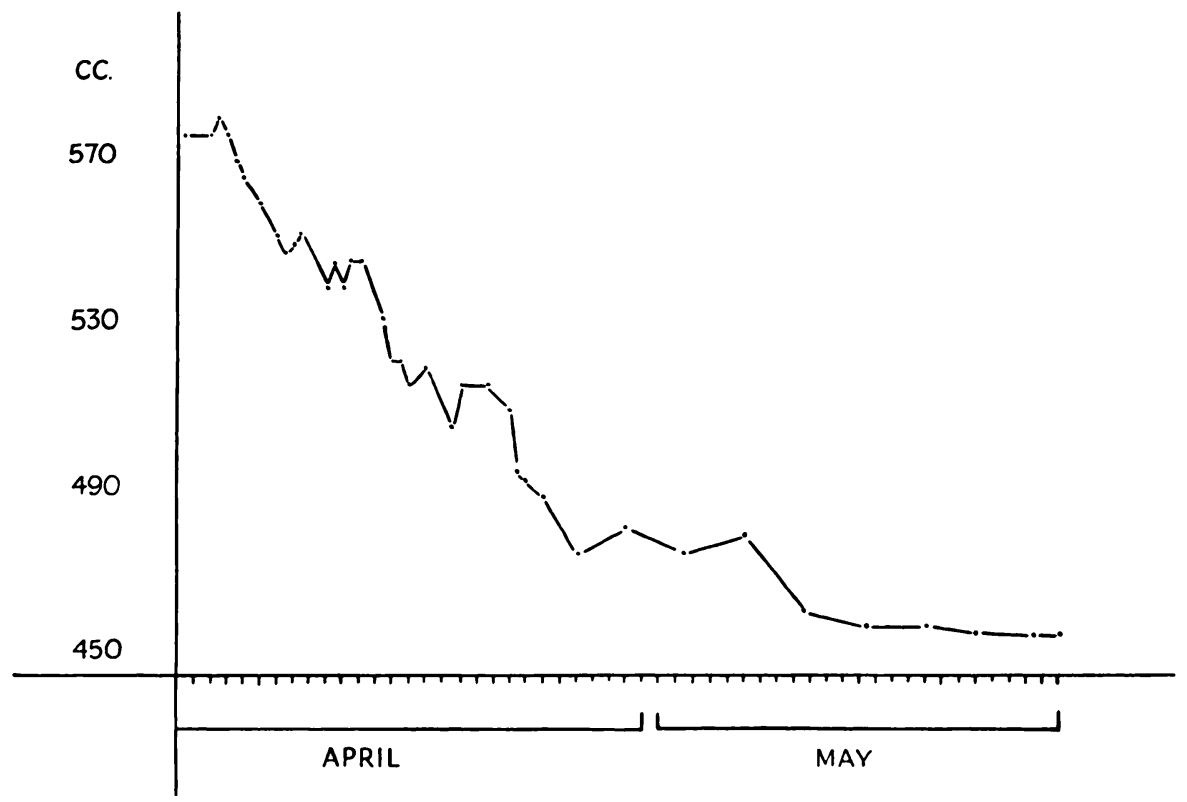

Fig. 9

Case 2-Volume chart of right hand. (Left hand 470 cubic centimetres.)

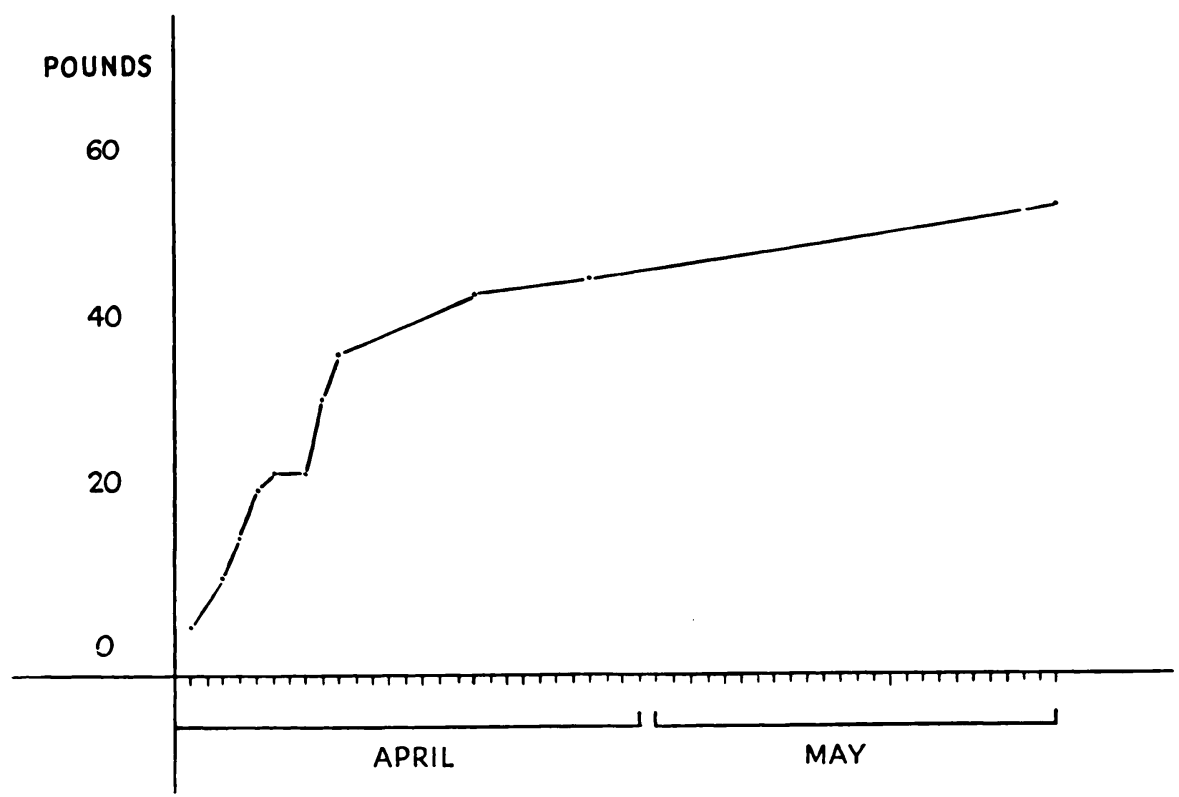

FIG. 10

Case 2-Power of grip chart, right hand. (Left hand $70 \mathrm{lb}$.)

From these observations it is clear that Sudeck's atrophy is nearly always accompanied by an alteration in the palmar fascia which may go on to a typical Dupuytren's contracture. These two conditions apparently have nothing in common except that they affect persons of about the same age. The fact that most of the cases reported in this paper occurred in women,

Vol. 38 B, NO. 1, FEBRUARY 1956 


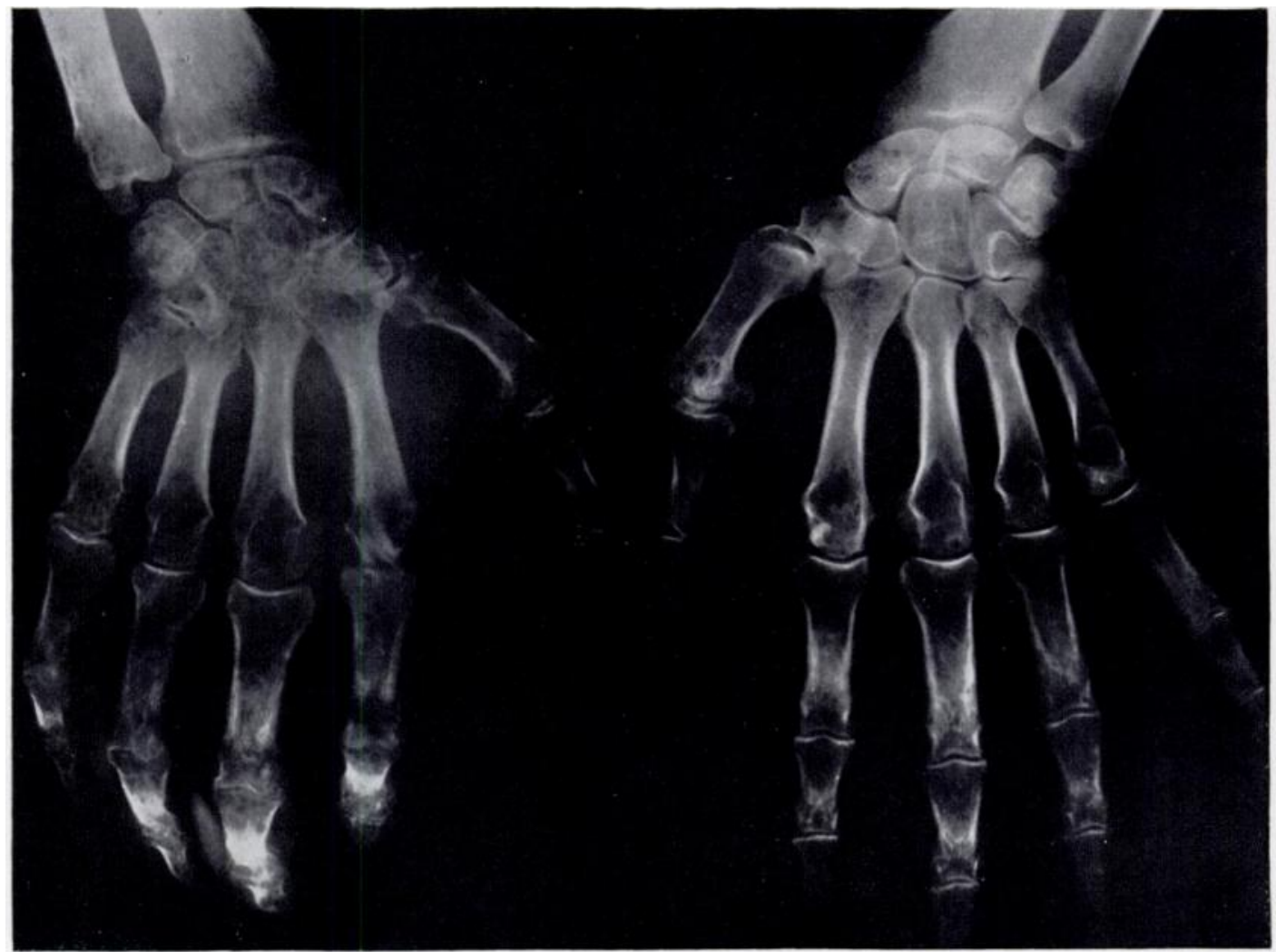

Fig. 11

Case 2-Well marked Sudeck's changes in the wrist and hand. There is typical spotty atrophy involving the carpus and the ends of the metacarpals and phalanges. The increase in soft-tissue shadow of the palm can be seen. The view of the last two phalanges of each finger is distorted because it is impossible to straighten the fingers. There is an old destructive lesion of the second metacarpo-phalangeal joint.

whereas Dupuytren's contracture is at least six times more common in men, may be explained by the higher incidence of wrist fractures in women. None of our patients was a known epileptic and none had knuckle pads (Skoog 1948).

\section{SUMMARY AND CONCLUSIONS}

1. The incidence of Sudeck's syndrome in the hand is about once in 2,000 accidents of all kinds.

2. The onset of signs and symptoms occurs some weeks after injury and the typical radiographic changes (spotty atrophy) appear six to eight weeks later.

3. Conservative treatment by heat, elevation and graded function is effective if initiated within six weeks of the onset of symptoms.

4. There is some close relationship between Sudeck's atrophy and thickening of the palmar fascia.

REFERENCES

Bethge, J., and Meyer, H. W. (1953): Die Sudeck’sche Erkrankung und ihre Behandlung mit Depot-Patudin. Medizinische, 1,520.

BiRKenfeld, B. (1954): Erfahrungen mit der Echinacin-Therapie beim Sudeckschen Syndrom. Therapie der Gegenwart, 93, 425.

Blum NSAAT, C. (1953): Die Behandlung und Begutachtung des Sudeckschen Syndroms. Archiv für Orthopädische und Unfall-Chirurgie, 45, 451.

Brandt, G. (1954): Betrachtungen zur Pathophysiologie des Sudeckschen Syndroms. Medizinische Klinik, 49, 600 . 
BRÜCKe, H. v. (1946): Úber die Behandlung trophischer Störungen (Dystrophisches Syndrom) an der obern Extremität durch Durchtrennung des thorakalen Grenzstranges. Schweizerische Medizinische Wochenschrift, 76, 762.

Bunnell, S. (1948): Surgery of the Hand. Second edition. Philadelphia, London, Montreal: J. B. Lippincott Company.

DE Wulf, A. (1953): Atrophie osseuse de Südeck et tuberculose. Acta Orthopaedica Belgica, 19, 112.

DWYer, A. F. (1952): Sudeck's Atrophy and Cortisone. Medical Journal of Australia, ii, 265.

Eccles, M. V. (1956): Hand Volumetrics. British Journal of Physical Medicine, 19, 5.

Evans, J. A. (1946): Sympathectomy for Reflex Sympathetic Dystrophy. Report of Twenty-nine Cases. Journal of the American Medical Association, 132, 620.

GAERTNER, W. (1954): Die Behandlung der Sudeckschen Erkrankung mit Vasculat. Therapie der Gegenwart, 93, 184.

GURD, F. B. (1938): Functional Disabilities After Simple Fracture. With Special Reference to Importance of Bone Atrophy in Prolongation of Disability. Surgery, Gynecology and Obstetrics, 66, 489.

HARfF, J., and STuth, H. W. (1954): Zum Problem des Sudeckschen Syndroms. Zeitschrift für Orthopädie, 84, 359.

Henderson, M. S. (1936): Acute Atrophy of Bone: Report of an unusual Case Involving the Radius and Ulna. Minnesota Medicine, 19, 214.

Herrmann, L. G. (1935): Some Clinical Aspects of Post-traumatic Painful Osteoporosis. Journal of Medicine, 16, 21.

Herrmann, L. G., Reineke, H. G., and Caldwell, J. A. (1942): Post-traumatic Painful Osteoporosis. A Clinical and Roentgenologic Entity. American Journal of Roentgenology, 47, 353.

Heyman, C. H. (1924): Osteoporosis Relieved by Sympathectomy. Journal of the American Medical Association, 82, 1,333 .

JordAN, H. H. (1940): After-care of Fractures with Special Reference to Delayed Union and Sudeck's Atrophy. Archives of Physical Therapy, 21, 25.

KIER, S. (1948): Remarks on the Prognosis of the Post-traumatic Dystrophy of the Extremities. Acta Orthopaedica Scandinavica, 17, 253.

KübleR, E. (1952): Der Einfluss des Ultraschalls auf das Sudeck'sche Syndrom. Strahlentherapie, 87, 575.

Litrle, N. (1939): Sudeck's Atrophy. Medical Journal of Australia, i, 263.

MART, T. (1954): Wesen und Behandlung des Sudeckschen Syndroms. Praxis, 43, 742.

Middleton, D. S. (1937): Post-traumatic Painful Osteoporosis (Sudeck's Atrophy). Glasgow Medical Journal, 127, 115 .

Moser, H. (1953): Uber Pathophysiologie, Klinik und Therapie der Sudeckschen Krankheit. Archiv für klinische Chirurgie, 275, 124.

MUMFORD, E. B. (1938): Roentgenotherapy in Acute Osteoporosis. A New Type of Treatment. Journal of Bone and Joint Surgery, 20, 949.

Noble, T. P., and Hauser, E. D. W. (1926): Acute Bone Atrophy. Archives of Surgery, 12, 75.

Nurra, A., and Franz, A. (1952): La malattia di Sudeck. Minerva Ortopedica, 3, 217.

Platt, Sir H., editor (1950): Modern Trends in Orthopaedics. London: Butterworth \& Co. (Publishers) Ltd. Roland, O. (1952): Unsere Erfahrungen mit Depot-Padutin. Zentralblatt für Chirurgie, 77, 1,147.

Rose, T. F. (1953): Sudeck's Post-traumatic Osteodystrophy of Limbs. Medical Journal of Australia, i, 185. Scheibe, G., and KARITZKY, B. (1954): Das funktionelle Hautcapillarbild bei der Sudeckschen Krankheit. Chirurg, 25, 202.

SCHLEIPEN, C. (1954): Beitrag zur medikamentösen Therapie der Sudeck'schen Knochenatrophie. Medizinische, 624.

SCHRÖTER, G. (1953): Das Sudecksche Syndrom als berufsbedingte Erkrankung. Zeitschrift für die gesamte Innere Medizin, 8, 69.

SIEBER, E., and MeISSNER, F. (1954): Stoffwechsel- und pathologisch-anatomische Untersuchungen der Muskulatur beim Sudeckschen Syndrom. Archiv für klinische Chirurgie, 278, 123.

SKOOG, T. (1948): Dupuytren's Contraction with Special Reference to Aetiology and Improved Surgical Treatment. Its Occurrence in Epileptics. Note on Knuckle-pads. Acta Chirurgica Scandinavica, 96, Supplementum 139.

SUDECK, P. (1900): Ueber die acute entzündliche Knochenatrophie. Archiv für klinische Chirurgie, $62,147$. Also: Verhandlungen der Deutschen Gesellschaft für Chirurgie, 29 (part 2), 673.

SUDECK, P. (1938): Die kollateralen Entzündungsreaktionen an den Gliedmassen (sog. akute Knochenatrophie). Archiv für klinische Chirurgie, 191, 710.

Toumey, J. W. (1948): Occurernce and Management of Reflex Sympathetic Dystrophy (Causalgia of the Extremities). Journal of Bone and Joint Surgery, 30-A, 883.

WATSON-JoNes, Sir R. (1952): Fractures and Joint Injuries. Fourth edition. Vol. 1. Edinburgh and London: E. \& S. Livingstone Ltd.

VOl. 38 B, No. 1, FEbruARY 1956 